\title{
Spermagglutination and Spermagglutinating Activity of Serum and Tissue Extracts from Reproductive Organs in Male Dogs Experimentally Infected with Brucella canis
}

\author{
Tadao SERIKAWA, Takehiko MURAGUCHI and Junzo YAMADA \\ Institute of Laboratory Animals, Faculty of Medicine, Kyoto University, \\ Konoe-cho, Yoshida, Sakyo-ku, Kyoto-shi, Kyoto 606
}

Hiroshi TAKADA

Safety Research Laboratory, Tanabe Seiyaku, Co., Ltd., Kashima, Yodogawa-ku, Osaka-shi, Osaka 532

(Received for publication July 1, 1980)

\begin{abstract}
Four adult male beagle dogs were inoculated orally with $3.2 \times 10^{8}$ Brucella canis. Agglutination of spermatozoa, head-to-head type, was found in the urine from the 11 th to 19 th week after the inoculation. Similar spermagglutination was observed in flush out fluids from the epididymal channel of 2 dogs at autopsy. Spermagglutinating activity was detected in sera by the Shulman's capillary tube method. The duration and strength of the agglutinating activity varied by dogs. The activity was also detected in extracts of testis and epididymis and in a flush out fluid from the epididymal channel of one dog. Fractionation experiments by gel filtration using Sephadex G-200 and preparative zone electrophoresis of the sera and the extracts showed that the spermagglutinating activity resided in immunoglobulin fractions. The spermagglutinating activity was not due to the agglutinating antibody to $B$. canis antigen and was heat stable at $56^{\circ} \mathrm{C}$ for $30 \mathrm{~min}$. These results suggest that the spermagglutination might be caused by the anti-sperm autoantibody. It was proposed that the spermagglutination might be a part of various causes of infertility of male dogs due to infection with $B$. canis.
\end{abstract}

Epididymitis, testicular atrophy and sterility have been reported in male dogs infected with Brucella canis, while in female dogs abortion is the main clinical sign $[2,3$, 8, 9]. The pathogenesis of infertility in male dogs has not been clarified yet. Recently, George et al. [4] serially examined changes of spermal morphology in experimentally induced canine brucellosis and described bent tail, head-tail detachment and head-to-head agglutination of spermatozoa as the major abnormality.

We found spontaneous agglutination of spermatozoa in the urine of experimentally infected male dogs. In this report we ex- amine the time-course of development of spermagglutination in urine and spermagglutinating activity of sera, and also describe some nature of spermagglutinating activity in the serum and tissue extracts.

\section{Materials and Methods}

Dogs and inoculation: Four male beagles, about 2 to 3 year old, obtained from $2 B$. canis free colonies were used. A strain of B. canis, K76-620, isolated from the retropharyngeal lymph node of a spontaneously infected $\operatorname{dog}$ was used. The organisms stored at $-20^{\circ} \mathrm{C}$ were incubated in Trypticase soy broth (Eiken) at $37^{\circ} \mathrm{C}$ for 4 days. The suspension of $B$. canis cells was adjusted to $3.2 \times 10^{8}$ colony forming units per $\mathrm{m} l$ with phosphate-buffered saline, pH 6.2 (PBS). All the dogs were in- 
oculated orally with $1 \mathrm{~m} l$ of the cell suspension and were kept individually.

Detection of $B$. canis and anti-B. canis antibody: The concentration of $B$. canis cells in blood and urine was examined weekly by the culture method described in the previous report [12]. Serum agglutinin titer was determined by the microtiter method using heat killed $B$. canis antigen, QE-13 strain, as described previously [13].

Spermagglutination in urinary sediment: Bladder urine samples collected using a catheter were immediately centrifuged at $1,000 \mathrm{rpm}$ for $5 \mathrm{~min}$. One drop of the urinary sediment was put on a microscope slide and air dried. The slides stained with giemsa solution were examined under a microscope.

Spermagglutinating activity: Spermagglutinating activity was examined by the capillary tube agglutination method developed by Shulman et al. [15, 16]. To collect epididymal spermatozoa, a male dog derived from a $B$. canis free colony was castrated. The cauda epididymis and part of the vas deference werc removed from the testis. Sperm was collected by forcing $1 \mathrm{~m} l$ of $0.15 \mathrm{M} \mathrm{NaCl}$ solution into the epididymal channel. Obtained unwashed sperm suspension $(0.025 \mathrm{ml})$ containing $4.0 \times 10^{7}$ motile cells per $\mathrm{ml}$ was mixed with the same volume of 2-fold serially diluted test samples, and this mixture was aspirated into a capillary tube of $6.5 \mathrm{~mm}$ diameter and $75 \mathrm{~mm}$ length. The tubes implanted vertically on a putty plate were incubated at room temperature, and examined for agglutination after $30 \mathrm{~min}, 1 \mathrm{hr}$ and $2 \mathrm{hr}$. The intensity of spermagglutination was recorded according to the criteria shown in Fig. 1 . Positive reactions were shown by the development of discrete opaque clumps which were separated from each other by clear regions. Negative reaction was easily recognized by homogenous turbid appearance throughout the fluid in the capillary tube. Spermagglutinating titer was expressed with the final dilution of samples showing positive reaction.

Preparation of extracts of the reproductive organs: Testes, epididymides or prostates were homogenized as $10 \%$ emulsion with $0.15 \mathrm{M} \mathrm{NaCl}$ solution and centrifuged at $10,000 \mathrm{rpm}$ for $15 \mathrm{~min}$ at $4^{\circ} \mathrm{C}$. The supernatants obtained were filtrated using millipore filter (pore size $0.45 \mu$ ).

Gel filtration: Three or $5 \mathrm{ml}$ of sera or tissue extracts was chromatographed on a Sephadex G-200 column ( 2.5 by $90 \mathrm{~cm})$ in $0.1 \mathrm{M}$ Tris- $\mathrm{HCl}$ buffer containing $0.15 \mathrm{M} \mathrm{NaCl}$. The sample was eluted with flow rate of about $12 \mathrm{~m} l$ per hr into 50 tubes, each containing $10 \mathrm{~m} l$. The optical density of each fraction was determined by spectrophotometer at
$280 \mathrm{~nm}$.

Preparative starch block electrophoresis: Preparative zone electrophoresis was performed using a tray $5 \times 1 \times 40 \mathrm{~cm}$ with starch as the supporting medium and barbiturate buffer, $\mathrm{pH} 8.6, \mu=0.05$. Three $\mathrm{m} l$ of serum was electrophoresed at $4^{\circ} \mathrm{C}$ for $36 \mathrm{hr}$ at $10 \mathrm{~mA}$ constant current. After the electrophoresis, the block was sliced into $1 \mathrm{~cm}$ in width. Ten $\mathrm{m} l$ of barbiturate buffer was added to each slice. The liquid portion was separated by centrifugation and an absorbency at $750 \mathrm{~nm}$ was read using a spectrophotometers on colors developed by the Folin-Lowry method.

Concentration of fractions: Fraction pools obtained by gel filtration or preparative electrophoresis were packed in cellophane tubes and concentrated by dialysis against saturated solution of polyethylene glycol 6,000 to an appropriate volume.

Immunoelectrophoresis and immunodiffusion tests: Immunoelectrophoresis was performed using a gel of $1.25 \%$ agar in barbiturate buffer, $\mathrm{pH}$ 8.6. Immunodiffusion test was carried out in agar gel of $1.25 \%$ according to the method of Ouchterlony. Sera, tissue extracts and their fraction pools were tested using rabbit sera prepared against either of whole $\operatorname{dog}$ serum, $\operatorname{dog} \operatorname{Ig} \mathrm{A}, \operatorname{Ig} \mathbf{G}$ or Ig M. These antisera were perchased from Miles Yeda, Co., Ltd., Indiana.

Absorption test: A $0.5 \mathrm{ml}$ of heavy concentration of heat killed $B$. canis cells, QE-13 strain, or of unwashed epididymal spermatozoa suspension was added to $1 \mathrm{~m} l$ of serum with agglutinating activity to both $B$. canis and spermatozoa. The mixtures were incubated, with occasional gentle shaking, at $37^{\circ} \mathrm{C}$ for $2 \mathrm{hr}$ for $B$. canis or at room temperature for $2 \mathrm{hr}$ for spermatozoa, and then they were kept overnight at $4^{\circ} \mathrm{C}$. The supernatants obtained by centrifugation, for $30 \mathrm{~min}$ at 10,000 rpm, were titrated for agglutinating activity against $B$. canis or spermatozoa.

\section{Results}

Spontaneous agglutination of spermatozoa in urine: Results of examination of spermatozoa in urine of $\operatorname{dog} \# 1$ and \#2 were summarized in Fig. 2 (A, B). The results of $\operatorname{dog} \# 3$ and \#4 were represented by the data of $\operatorname{dog} \# 1$, because their data showed a similar tendency. Spermatozoa were detected in more than 50 percent of urine samples throughout the observation period in dogs of \#1, \#3 and \#4, but in 

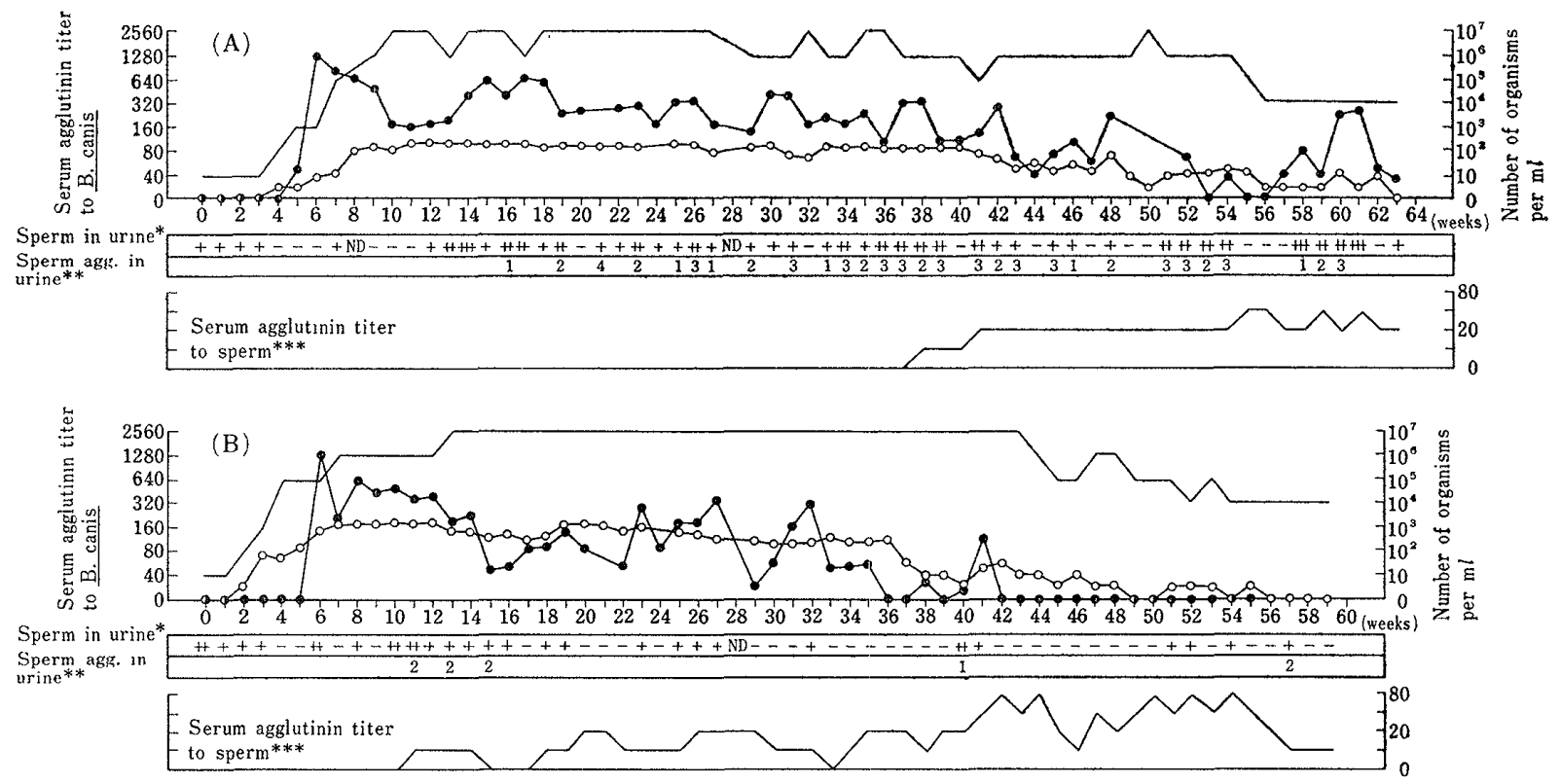

Fig. 2. A long-term observation on concentrations of B. canis and sperm in urine and of B. canis in blood, spermagglutination in urine, and spermagglutinin titer to $B$. canis and sperm in 2 male dogs experimentally infected with $B$, canis.

(A): $\operatorname{dog} \# 1,(B): \operatorname{dog} \# 2$,

* Concentration of sperm in urine.

* Degree spermagglutination in urine.

*** Serum agglutinin titer to sperm by the capillary tube agglutination test method.

$(-)$ : Serum agglutinin titer to B. canis. $(-\mathrm{O}-)$ : B. canis in blood. (- - ) B. canis in urine.

$\operatorname{dog} \# 2$ the frequency decreased especially from the 30th week after the inoculation. The concentration of spermatozoa in urine was expressed per 1 drop of urine as follows; +: 1-10 sperm, H: 11-50 sperm, H: more than 51 sperm and $\mathrm{HW}$ : countless sperm. Spontaneous agglutination of spermatozoa was found in the urine of all dogs infected with B. canis. All the agglutination was head-to-head type, showing various intensity as shown in Figs. 3-5. The degree of agglutination was graded as follows; 1 : 1-10 sperm/clump with many free sperm, 2: 1-10 sperm/clump with some free sperm or 11-50 sperm/clump with many free sperm, 3: 11$50 \mathrm{sperm} /$ clump with no free sperm or more than 51 sperm/clump with some free sperm, 4: more than 51 sperm/clump with no free sperm. The spermagglutination was found after the 11 th-19th week. At that time $B$. canis organisms were already detected both in the blood and urine, and anti-B. canis serum agglutinin was developed.

The head-to-head spermagglutination was also observed in a specimen from epididymal channel of dog \#2 when autopsied 59 weeks after the inoculation. When $\operatorname{dog} \# 1$ was examined 63 weeks after the inoculation, 80 percent of spermatozoa collected from the right epididymal channel showed spontaneous agglutination or bent tail. On the other hand, spermagglutination was not detected on spermatozoa obtained from the left epididymal channel, while 82 percent of the spermatozoa showed head-tail detachment.

Detection of spermagglutinating activity in the serum and organ: In 3 of 4 dogs, serum spermagglutinating activity was detected well later than the appearance of spermagglutination in urine as shown in Fig. 2(A). In dog \#2 serum spermaggluti- 


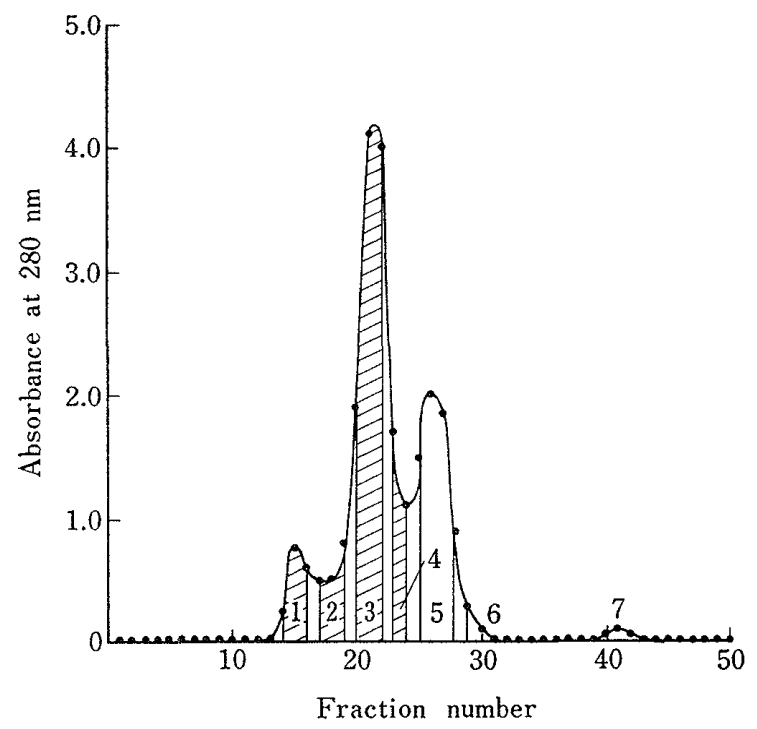

Fig. 6. Gel filtration pattern of spermagglutinating serum (dog \#4, $42+44$ weeks, $3 \mathrm{ml}$ ) and fraction pools having the activity.

Column: Sephadex $\mathrm{G}-200$ in $0.1 \mathrm{M}$ Tris- $\mathrm{HCl}$ buffer. $\mathrm{pH} 8.0,0.15 \mathrm{M} \mathrm{NaCl}, 2.5$ by $90 \mathrm{~cm}$. Flow rate: $12 \mathrm{ml} / \mathrm{hr}$.

$10 \mathrm{ml}$ fractions were collected.

Pooled fractions are indicated as $\# 1-\# 7$.

Spermagglutinating activity was detected in \#1-\#4 of pooled fractions shown as diagonally hatched areas in the figure.

nating activity was detected almost at the same time as the spermagglutination was first observed in the urine. In dogs \# 1 and \#2 the serum spermagglutinating activity persisted until the experiment was terminated. On the other hand, in dogs \#3 and \#4 it disappeared at the time of sacrifice, 34 and 63 weeks after the inoculation, respectively,

The extracts of the reproductive organs and the flush out fluids from epididymal channels of $\operatorname{dogs} \# 1, \# 2$ and \#4 were also examined for the presence of spermagglutinating activity. The activity was detected only from the extracts of dog \#2. The agglutinating titers were 100 in the testis, 400 in the epididymis and 200 in flush out fluid from the epididymal channel. The extract of the prostate did not react with spermatozoa.

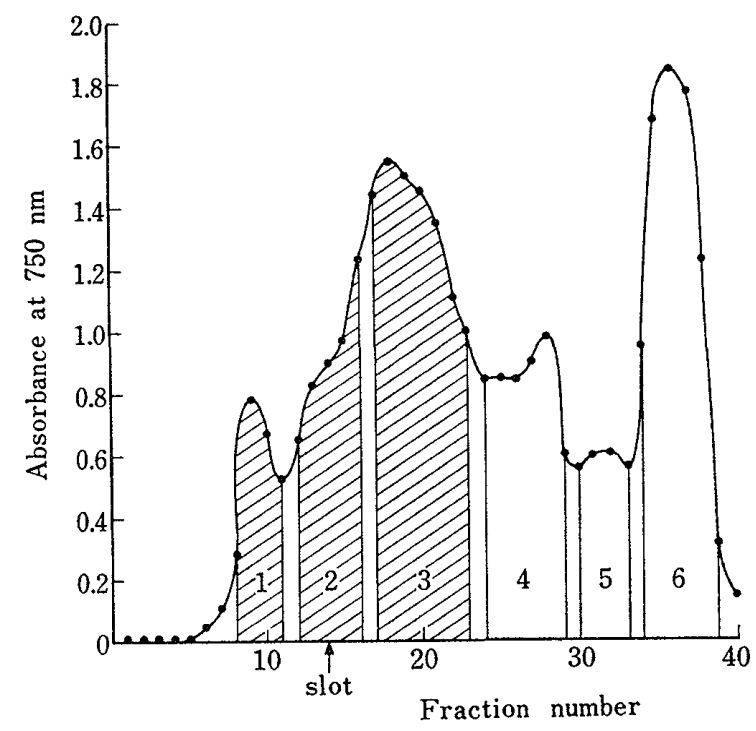

Fig. 7. Electrophoretic pattern in a starch block of spermagglutinating serum ( $\operatorname{dog} \sharp 2,50+52$ weeks, $3 \mathrm{ml}$ ) and fraction pools having the activity.

Starch block: $5 \times 1 \times 40 \mathrm{~cm}$, Buffer: Barbiturate buffer $\mathrm{pH} 8.6, \mu=0.05$, Electrophoresis: $10 \mathrm{~mA}, 180 \mathrm{~V}, 36$ $\mathrm{hr}$. At the end of the run, fractions were extracted with $10 \mathrm{ml}$ of the buffer from each $1 \mathrm{~cm}$ segment of the block.Absorbency at $750 \mathrm{~nm}$ of fractions was read using a spectrophotometer on colors developed by the Folin-Lowry method.

Pooled fractions are indicated as $\# 1-\# 6$.

Spermagglutinating activity was detected in $\# 1-\# 3$ of pooled fractions shown as diagonally hatched areas in the figure.

Nature of the spermagglutinating activity: The spermagglutinating activity of the sera was not abolished by heating at $56^{\circ} \mathrm{C}$ for $30 \mathrm{~min}$. A spermagglutinating serum was fractionated by Sephadex G-200 gel filtration. The activity was distributed in the pooled fractions \#1-\#4 (Fig. 6). In addition, another spermagglutinating serum was also fractionated by preparative starch block electrophoresis and the activity was detected in the pooled fractions \#1-\#3, so-called $\gamma$ globulin to $\beta$-globulin regions, as shown in Fig. 7. Immunoelectrophoresis showed that immunoglobulin was contained in each fraction pool having spermagglutinating activity as shown in Figs. 8 and 9.

The extracts of testis and epididymis with 


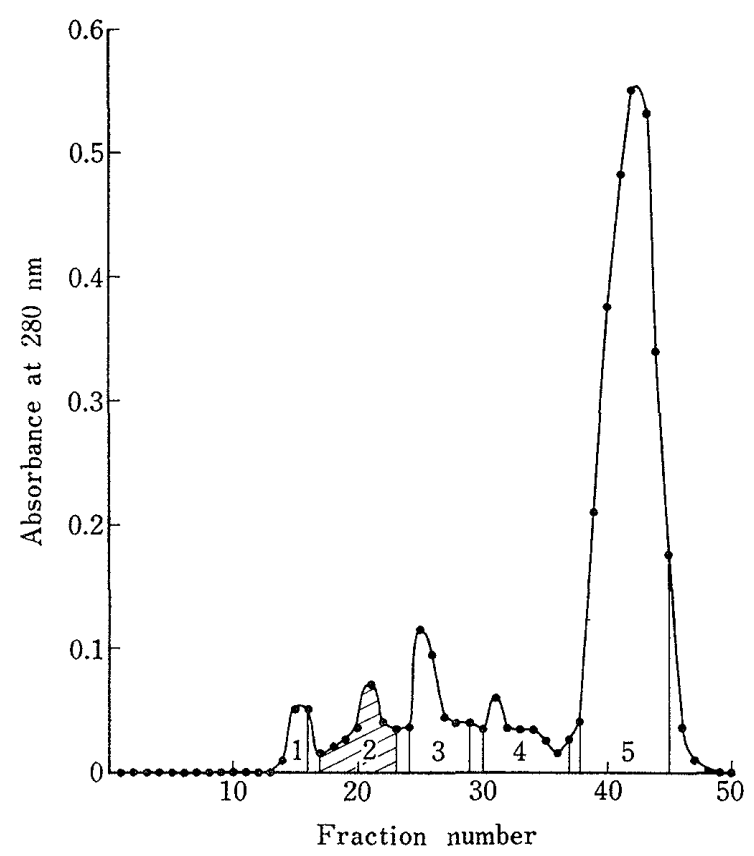

Fig. 10. Gel filtration pattern of spermagglutinating extract of testis ( $\operatorname{dog} \sharp 2,5 \mathrm{ml}$ ) and fraction pool having the activity.

Column: Sephadex $\mathrm{G}-200$ in $0.1 \mathrm{M}$ Tris- $\mathrm{HCl}$ buffer, $\mathrm{pH} 8.0,0.15 \mathrm{M} \mathrm{NaCl}, 2.5$ by $90 \mathrm{~cm}$. Flow rate: $12 \mathrm{ml} / \mathrm{hr}$.

$10 \mathrm{ml}$ fractions were collected.

Pooled fractions are indicated as $\# 1-\# 5$.

Spermagglutinating activity was detected only in \#2 of pooled fractions shown as diagonally hatched area in the figure.

spermagglutinating activity were also fractionated on a column of Sephadex G-200 (Figs. 10 and 11). Immunoelectrophoresis showed that immunoglobulin was contained in the fractions having spermagglutinating activity as shown in Figs. 12 and 13. It was confirmed by the immunodiffusion test that the immunoglobulin was Ig $\mathrm{G}$ but not Ig A or Ig M (Fig. 14).

The sera with agglutinating activity both to $B$. canis and spermatozoa were used for absorption tests. The sera completely abolished the agglutinating activity to $B$. canis by absorption with the organisms, but these absorbed sera still showed spermagglutinating activity. Contrary, the absorption of the sera with the sperm suspension completely eliminated the agglutinating ac-

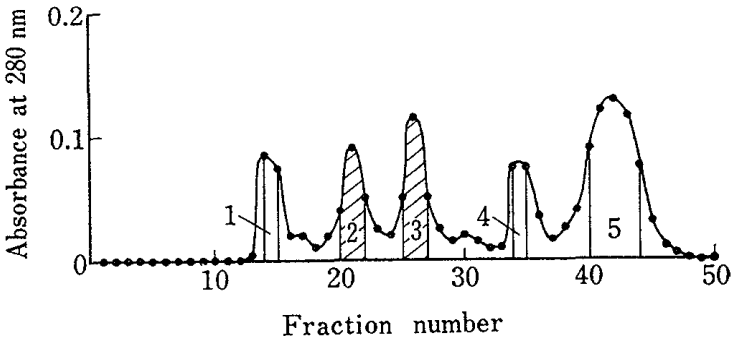

Fig. 11. Gel filtration pattern of spermagglutinating extract of epididymis ( $\operatorname{dog} \sharp 2,5 \mathrm{ml}$ ) and fraction pools having the activity.

Column: Sephadex G-200 in $0.1 \mathrm{M}$ Tris- $\mathrm{HCl}$ buffer. pH 8.0. $0.15 \mathrm{M} \mathrm{NaCl}, 2.5$ by $90 \mathrm{~cm}$. Flow rate : $12 \mathrm{ml} / \mathrm{hr}$.

$10 \mathrm{ml}$ fractione were collected.

Pooled fractions are indicated as $\# 1-\# 5$.

Spermagglutinating activity was detected in $\# 2$ and \#3 of pooled fractions shown as diagonally hatched areas in the figure.

tivity to spermatozoa without any decrease of agglutinating titer to $B$. canis.

\section{Discussion}

The morphological abnormalities of spermatozoa appeared in urine have to be judged after due consideration on a harmful effect of urine on sperm morphology. The head-to-head spermagglutination detected in dogs with canine brucellosis, however, seems to be accounted as a characteristic abnormality, since such spermagglutination was found not only in urine but also in epididymal fluid. In addition, spermagglutinating activity was detected in sera, in the extracts of the epididymis and testis and in epididymal fluid. The spermagglutinating activity in sera resided in the 1 st to 2 nd peaks of Sephadex G-200 chromatography and in $\gamma$-globulin to $\beta$-globulin regions in preparative zone electrophoresis. These characteristics coincide with that of canine immunoglobulins $[6,7,10]$. Furthermore, the fractions with spermagglutinating activity obtained from organ extracts by gel filtration on Sephadex G-200 were shown to contain Ig G. These findings suggested 
that the spermagglutinating activity was caused by antibodies against their own sperm, i.e. an autoantibody, and that spermagglutinates in urine and epididymal fluid were caused by the antibodies. It seems that spermagglutinates in the bladder urine are formed during passage through the vas deference, epididymal channel or more upper portion of ducts, although they might be accelerated to form a large clump in urine. The antisperm autoantibody might be produced both systemically and locally, because agglutination of spermatozoa in urine was developed earlier than spermagglutinating activity in serum in 3 out to 4 cases. Although Ig A or Ig $\mathrm{M}$ was not detected in tissue extracts and epididymal fluid, they might already be lost during the extraction process as their concentrations were low in the organs. These problems will be clarified by immunofluorescence technique using labelled anti-canine immunoglobulins in near future.

The spermagglutinating activity seems not relate to the antibody to $B$. canis, because no common antigen between the bacteria and spermatozoa was confirmed by absorption tests performed on sera with both activities. This was further supported by the facts that the spermagglutinating activity was not detected in sera of a female dog collected weekly up to 80 weeks after the oral inoculation with $B$. canis (unpublished observation), and that in the male dogs, the intensity of the serum spermagglutination was not in parallel with the serum agglutinin titer to $B$. canis.

The mechanism of the sperm autoantibody formation in human cases has been studied by several workers. Ansbacher et al. [1] showed that sperm autoantibody developed in about 60 percent of men in the first year after the vasectomy. The cause was explained by the blockage of sperm passage causing extravasation of considerable numbers of spermatozoa into the interstitial tissue and this subsequently led to the stimulation of antibody formation to the sperm [11, 14]. Haesch et al. [5] reported that more than half of patients with sperm antibodies had experienced inflammations of testes or epididymides, including gonorrhea, tuberculosis and parotitis in some cases. In canine brucellosis, localization or multiplication of $B$. canis in male reproductive organs seems to be an indispensable factor for the appearance of sperm autoantibody in body fluids. This was supported by the fact that spermagglutinates in urine appeared 1 to 2 months after $B$. canis organisms were first detected in urine. In this study, the mechanism of autoantibody formation and its consequential effect on the spermatogenesis were not clarified yet, but it may be conceivable that head-tohead agglutination of spermatozoa might interfere with the normal fertilization process.

Acknowledgments. The authors wish to Thank Dr. K. Ueda, of the Institute of Public Health, Japan, and Prof. Dr. Y. Bito and Dr. T. Kajikawa, of Osaka Prefectural University, for helpful advice.

\section{References}

[I] Ansbacher, R., Keung-Young, K., and Wurcher, J. C. (1972). Serum antibodies in vasectomized men. Fertil. Steril. 23, 640-643.

[2] Carmichael, L. E., and Kenny, R. M. (1969). Canine abortion caused by Brucella canis. J. Am. Vet. Med. Assoc. 152, 605-614.

[3] Carmichael, L. E., and Kenny, R. M. (1970). Canine brucellosis: The clinical disease, pathogenesis, and immune response. J. Am. Vet. Med. Assoc. 156, 1726-1736.

[4] George, L. W., Dunchan, J. R., and Carmichael, L. E. (1979). Semen examination in dogs with canine brucellosis. Am. J. Vet. Res. 40, 1589-1595.

[5] Haensch, R. (1969). Fluorescenzimmunologiesche spermienantikörper-befunde bei männlichen fertilitatstörungen. Arch. Gynäk. 208, 91-102. 
[6] Jonson, J. S., Vaughan, J. H. (1967). Canine immunoglobulins. I. Evidence for six immunoglobulin classes. J. Immunol. 98, 923234.

[7] Jonson, J. S., Vaughan, J. H., and Swisher, S. N. (1967). Canine immunoglobulin. II. Antibody activities in six immunoglobulin classes. J. Immunol. 98, 935-940.

[8] Moore, J. A. (1968). Brucella canis infection in dogs. J. Am. Vet. Med. Assoc. 155, 20342037.

[9] Moore, J. A., and Kakuk, T. J. (1969). Male dogs naturally infected with Brucella canis. $J$. Am. Vet. Med. Assoc. 155, 1352-1358.

[10] Patterson, R., Roberts, M., Pruzansky, J. J. (1968). Types of canine serum immunoglobulins. J. Immunol. 101, 687-694.

[11] Rümke, P., and Hekman, A. (1971). Autoand iso-immunity to sperm in infertility. Clin. Endocrinol. Metab. 4, 473-496, 1971.
[12] Serikawa, T., Muraguchi, T., and Nakao, N. (1977). A survey of dogs from Gifu and Shiga areas for Brucella canis. Jpn. J. Vet. Sci. 39, 635-642.

[13] Serikawa, T., Muraguchi, T., Nakao, N., and Yamada, J. (1977). A new microtiter plate agglutination method for Brucella canis antibodies. Exp. Anim. 26, 139-141.

[14] Shulman, S. (1972). Review. Immunologic barriers to fertility. Obstet. Gynecol. Surv. 27, 553-604.

[15] Shulman, S., and Hekman, A. (1971). Autoantibodies to spermatozoa. I. A new microscopic agglutination technique for their detection, using immotile sperm. Clin. Exp. Immunol. 9, 137-146.

[16] Shulman, S., Hekman, A., and Pann, C. (1971). Antibodies to spermatozoa. II. Spermagglutination techniques for guinea-pig and human cells. J. Reprod. Fertil. 27, 31-41.

Brucella canis 実験感染雄イヌにおける精子凝集と血清执よび生殖器組織抽出液の精子凝集活性：芹 川忠夫・村口武彦・山田澋三（京都大学医学部附属動物実験施設）, 高田 博 (田辺製薬, 安全性研究 所)—— 頭の雄ビーグル犬に $3.2 \times 10^{8}$ 個の Brucella canis を経口接種した. 接種 $11 \sim 19$ 週後から 全頭の尿中に頭部対頭部型の凝集精子を検出し，同様の凝集精子を 2 頭の精䉾上体管の内液中にも認め た. Shulman の毛細管法によって血清中に精子凝集活性が検出できた。この活性の継続期間とその力 価には個体差汃認められた，精子凝集活性は 1 頭の精巣と精巣上体の担出液抢よび精巣上体管の内液に も検出できた．Sephadex G-200を用いたゲル沪過と分離用ゾーン電気泳動による血清执よび組織液の 分画実験によって，精子凝集活性が免疫グロブリン分画にあることがわかった。この精子凝集活性付 B. canis 抗原に詨する凝集抗体に起因せず， $56^{\circ} \mathrm{C} 30$ 分間の加熱処理後もその凝集活性を失わなかっ

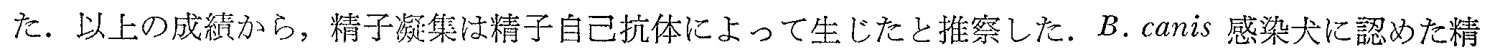
子凝集は不妊の重要な一原因となると考えられる. 


\section{Explanation of Figures}

Fig. 1. Selected capillary tubes showing various grades of spermagglutination. The first 2 tubes (from left) are positive $(H,+$ ) the third is \pm , and the last tube is negative.

Fig. 3. Microscopic view of head-to-head agglutinations of canine spermatozoa in urinary sediment of a $\operatorname{dog}$ infected with $B$. canis.

Fig. 4. Microscopic view of some moderate agglutinates of canine spermatozoa in urinary sediment of a dog infected with $B$. canis.

Fig. 5. Microscopic view of a large agglutinates of caine spermatozoa in urinary sediment of a dog infected with $B$. canis.

Fig. 8. Immunoelectrophoresis of pooled fractions of a spermagglutinating serum separated by gel filtration on Sephadex G-200 (see Fig. 6). The pooled fractions concentrated to $3 \mathrm{~m} l$ using polyethylene glycol 6,000 were applied. Trough was filled with rabbit anti-whole $\operatorname{dog}$ serum. S: Whole dog serum (dog \#2,50+52 weeks). 1-7: Pooled fractions \#1-7.

Fig. 9. Immunoelectrophoresis of pooled fractions of a spermagglutinating scrum separated by a starch block electrophoresis (see Fig. 7). The pooled fractions concentrated to $3 \mathrm{ml}$ using polyethylene glycol 6,000 were applied. Trough was filled with rabbit anti-whole dog serum. S: Whole $\operatorname{dog}$ serum ( $\operatorname{dog} \# 2,42+44$ weeks). 1-6: Pooled fractions \#1-6.

Fig. 12. Immunoelectrophoresis of pooled fractions obtained by gel filtration on Sephadex G-200 of a spermagglutinating extract of testis (see Fig. 10). The pooled fraction concentrated to $1 \mathrm{~m} l$ using polyethylene glycol 6,000 were applied. Trough was filled with rabbit antiwhole $\operatorname{dog}$ serum. T: Crude extract of testis (dog \#2). 1-5: Pooled fractions \#1-5.

Fig. 13. Immunoelectrophoresis of pooled fractions obtained by gel filtration of Sephadex G-200 of a spermagglutinating extract of epididymis (see Fig. 11). The pooled fractions concentrated to $0.5 \mathrm{~m} l$ using polyethylene glycol 6,000 were applied. Trough was filled with rabbit anti-whole dog serum. E: Crude extract of epididymis (dog \#2). 1-5: Pooled fractions \# I-5.

Fig. 14. Immunodiffusion test of spermagglutinating extract of testis and epididymis. F: Flush out fluid from epididymal channel. A: Anti$\operatorname{dog} \operatorname{Ig}$ A. G: Anti-dog Ig M. W: Anti-whole dog serum. 


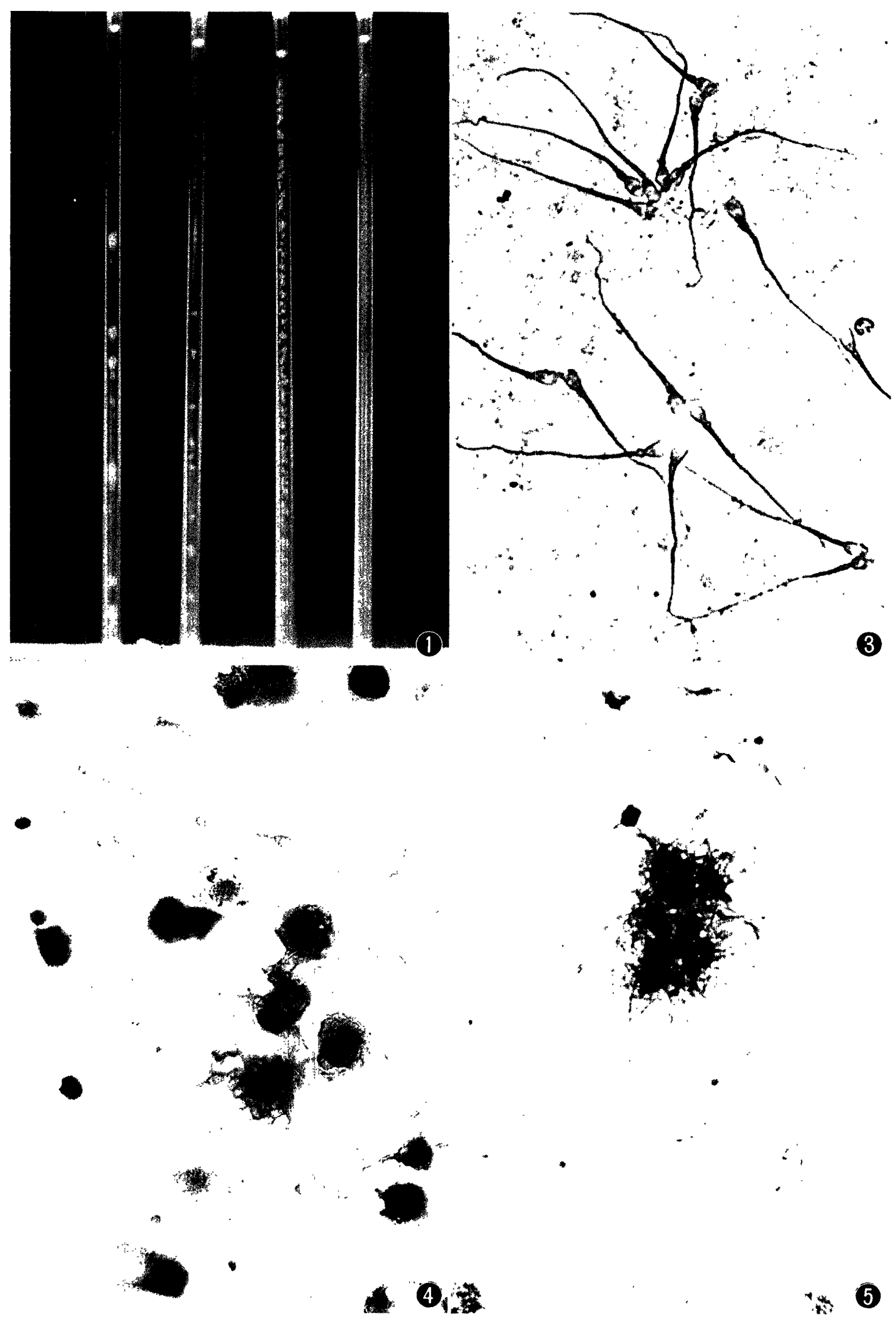



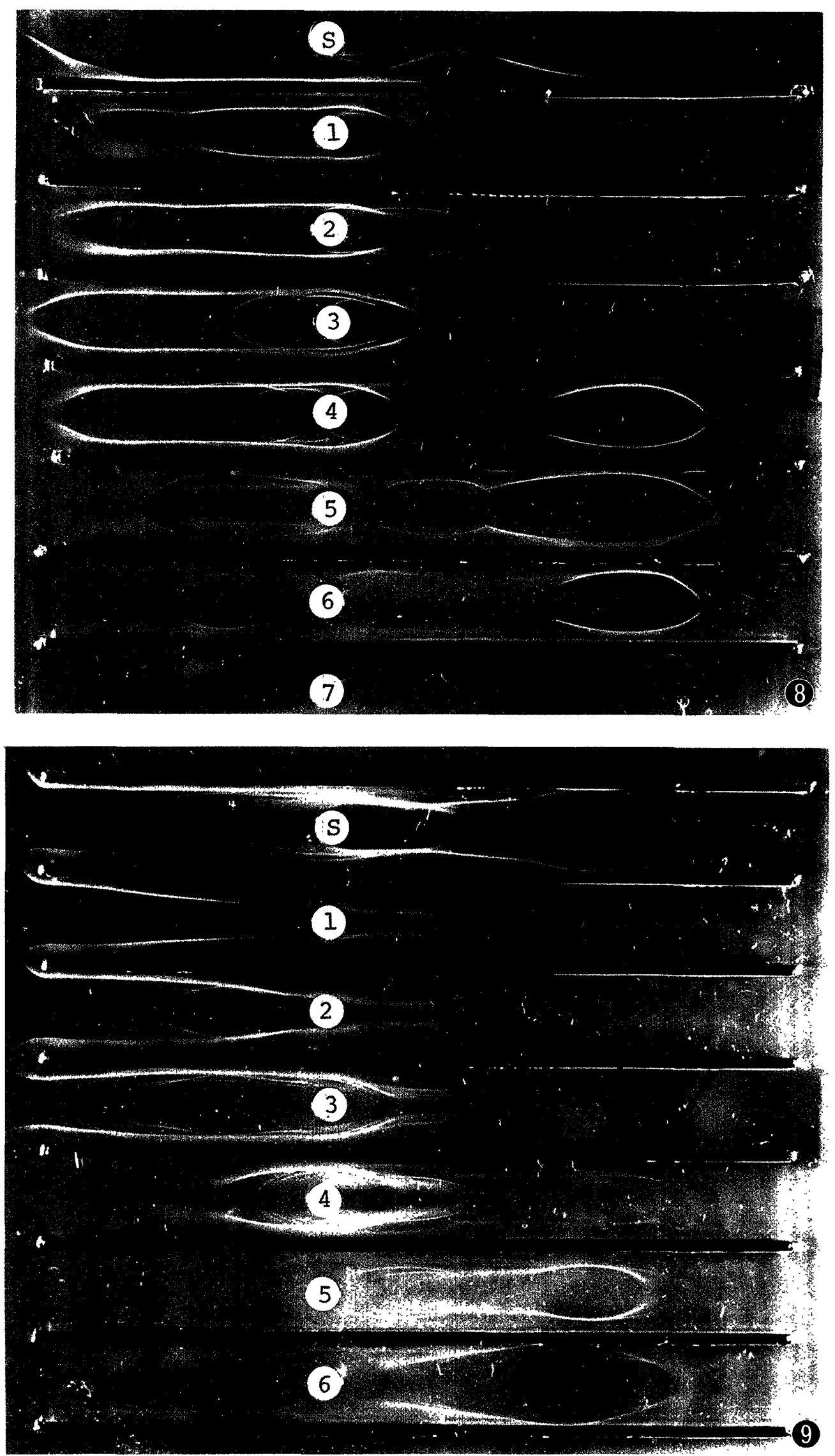

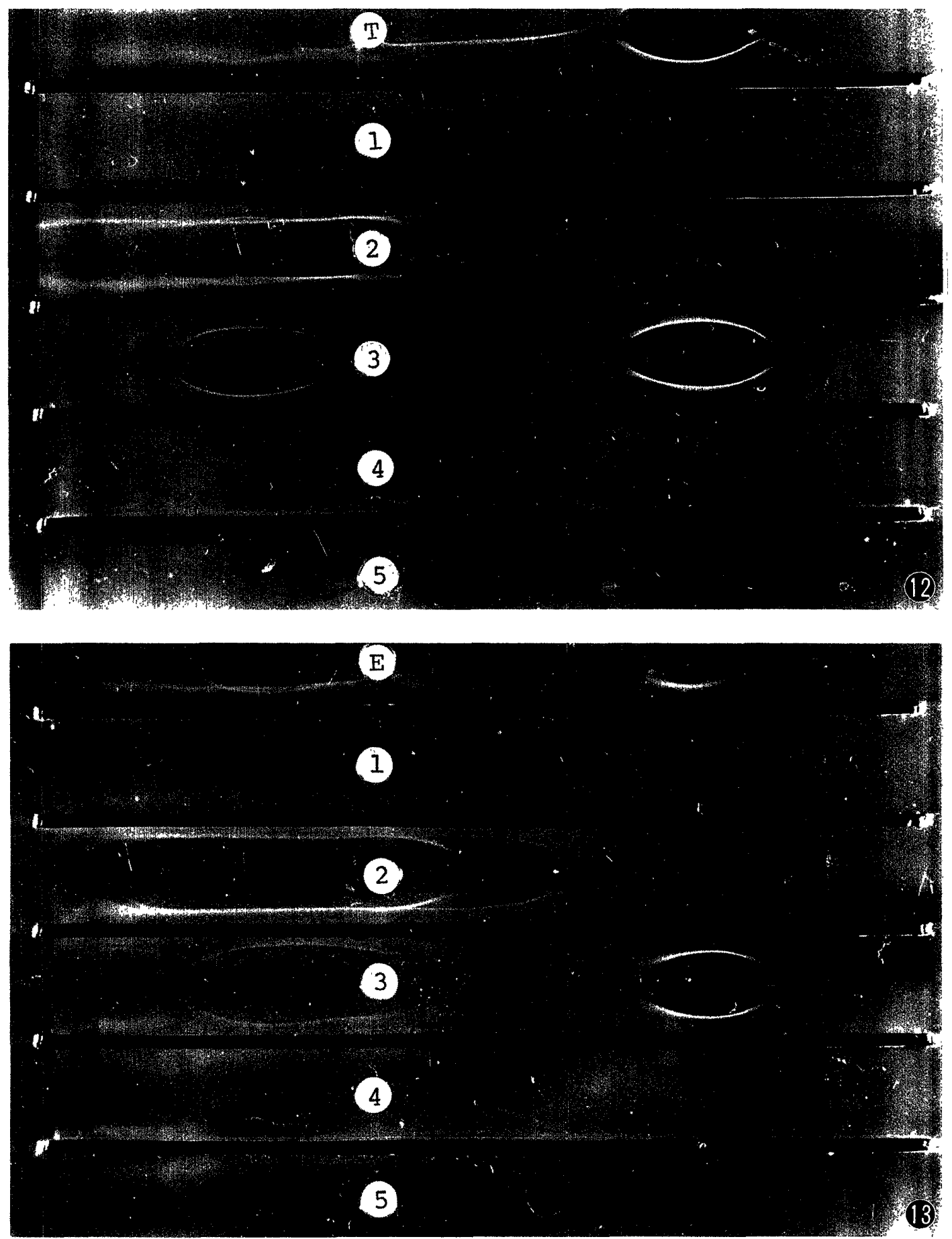

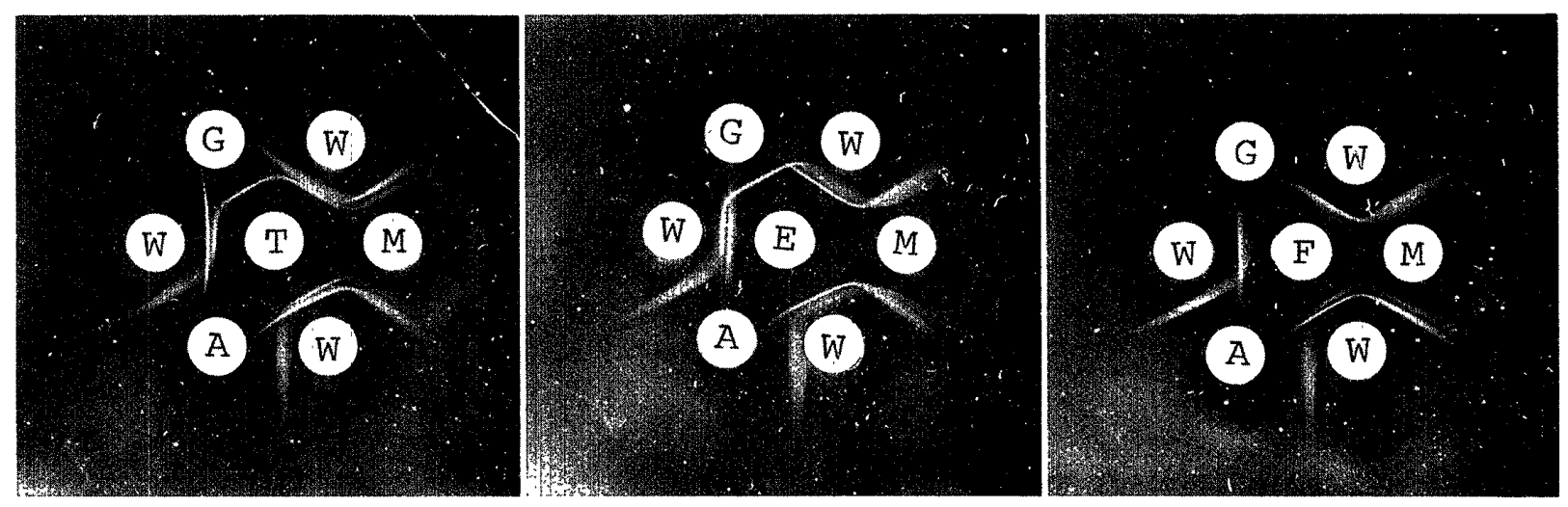

(14) 